ŁUKASZ JANKOWSKI

Instytut Historii UMK

\title{
Kolonie francuskie latach 1940-45
}

Erancja była drugim, po Wielkiej Brytanii, największym co do liczby - mieszkańców i powierzchni imperium kolonialnym na świecie. Jej posiadłości znajdowały się w Azji, Afryce, Ameryce Południowej i Północnej. Zamieszkiwało je 69,6 mln ludności, w tym 41,9 mln we Francji. Łączna powierzchnia wszystkich kolonii wynosiła 11.858 tys. $\mathrm{km}^{2}$ (sama Francja europejska miała 551 tys. $\left.\mathrm{km}^{2}\right)^{1}$.

W I poł. XX w. francuskimi terenami kolonialnymi były: Indochiny, Polinezja Francuska, Gujana Francuska, Antyle Francuskie, Saint Pierre i Miquelon, Francuska Afryka Zachodnia, Francuska Afryka Równikowa, Maroko, Algieria, Tunezja, Syria i Liban, Francuskie Somalii, Komory, Madagaskar, Nowa Kaledonia ${ }^{2}$.

Zarząd nad koloniami sprawowało od 30 stycznia 1934 roku utworzone z Ministerstwa Kolonii - Ministerstwo Francji Zamorskiej. W celu lepszej organizacji zarządu największych obszarów kolonialnych, stworzono federację kolonialne z gubernatorami generalnymi na czele. I tak od $1887 \mathrm{r}$. istniała federacja Indochin, w 1902 r. powstała Francuska Afryka Zachodnia, a w 1910 r. Francuska Afryka Równikowa. Wyjątkiem był Madagaskar, który nie tworzył federacji, a posiadał mimo to swego gubernatora generalnego. W Maroku, Tunezji, Annanie z Tonkinem, Kambodży i Laosie, władzę z ramienia Republiki Francuskiej posiadali rezydenci generalni. Natomiast gubernato-

J. Krasuski, Wspólnota francuska w Afryce, Poznań 1983, s. 13.

J. Baszkiewicz, Historia Francji, Wrocław-Warszawa-Kraków 1999, s. 516. 
rzy sprawowali zarząd nad Wyspami Gwadelupy, Martyniki, Reunion i francuskiej części Gujany³.

Status prawny kolonii, choć był z założenia zróżnicowany, to w praktyce nie miał on prawie znaczenia. Ingerencja władz francuskich była duża np. w Maroku i Tunezji, które były protektoratami, jeszcze silniejsza w Annamie, Tonkinie, Laosie i Kambodży. Fikcją była też samodzielność Królestwa Mossi w Wolcie Górnej. ${ }^{4}$ Trochę inaczej wyglądała pozycja Libanu i Syrii, które były zdobyczami na Imperium Osmańskim oraz Togo i Kamerunu odebranym Niemcom po I Wojnie Światowej. Posiadłości bliskowschodnie jako mandaty typu A Ligi Narodów, miały w pierwszej kolejności w przyszłości odzyskać niepodległość. Z kolei tereny afrykańskie, jako mandaty typu B, otrzymały tylko obietnicę jej uzyskania, a samodzielną władzę prowadziły tylko na polu administracji, ale nie polityki.

W nocy z 9 na 10 maja 1940 r. wojska niemieckie zaatakowały Holandię, Belgię i Luksemburg. 21 maja Niemcy docierają do Kanału Brytyjskiego, gdzie w okolicach Dunkierki zamykają siły francusko-brytyjskie. Bitwa kończy się 4 czerwca klęską Aliantów, których część udało się ewakuować na Wyspy. Włochy wypowiedziały wojnę Francji 10 czerwca. Cztery dni później, Wehrmacht opanowuje Paryż. Nowo mianowany premier rządu francuskiego - Filip Petain 22 czerwca podpisuje zawieszenie broni z Niemcami, a dwa dni później z Włochami. Francja została podzielona przez zwycięzców na strefy:

a) okupowaną, która obejmowała cała Francję północną i środkową po Loarę oraz całe wybrzeże atlantyckie do granicy hiszpańskiej - łącznie około 2/3 terytorium;

b) Alzację i Lotaryngię, które wcielono bezpośrednio do Rzeszy;

c) nieokupowaną, która obejmowała południową część, z której 12 lipca, marszałek Petain proklamował powstanie Państwa Francuskiego (przedtem Francja była określana jako „Republika”).

Siedzibą rządu miało być miasto Vichy. Państwo to miało zachować swą flotę, lecz miała ona pozostać unieruchomiona w portach, pozostawiono nienaruszone imperium kolonialne i licząca 100 tys. armię rozejmową. Co więcej, nowe Państwo Francuskie było zmuszone utrzymać wojska niemieckie stacjonujące we Francji, a Hitler zastrzegł sobie prawo do bezwarunkowego zerwania zawieszenia broni, jako środka do wpływania na możliwy opór rządu Vichy, na niewykonywanie dyrektyw z Berlina 5 .

\footnotetext{
J. Krasuski, dz.cyt., s. 25.

Tamże, s. 13.

${ }^{5}$ J. Eisler, Kolaboracja we Francji 1940-1944, Warszawa 1988, s. 73.
} 
Nim upadł Paryż, w łonie rządu francuskiego coraz wyraźniej rysował się podział na tzw. „twardych”, którzy byli za prowadzeniem wojny aż do końca, w razie zajęcia Francji miała być ona dalej prowadzona z jej terytoriów zamorskich, a rząd miał przenieść się do Afryki Północnej (Algierii); i „miękkich”, którzy uważali za konieczne doprowadzenie do zawieszenia broni. Wśród zwolenników walki znajdowali się tylko Reynaud, Mandel (minister kolonii, a od 18 maja - minister spraw wewnętrznych) i podsekretarz stanu w Ministerstwie Obrony Narodowej - gen. de Gaulle ${ }^{6}$.

Wobec naporu wojsk niemieckich, rząd francuski postanowił ewakuować się na południe. 14 lipca władze dotarły do Bordeaux. Tutaj już wykrystalizowały się dwa ośrodki władzy: formalny wokół premiera Reynaud oraz nieformalny wokół pozostającego na razie na uboczu Lavala ${ }^{7}$. Wobec możliwości deklaracji Stanów Zjednoczonych dot. ewentualnej pomocy, oba stronnictwa zajęły postawę wyczekującą. Natomiast rząd brytyjski poprzez przebywającego w Londynie gen. de Gaulle'a, wysunął propozycję do strony francuskiej. Miało to miejsce 16 czerwca i dotyczyło możliwości zawarcia unii, która miała łączyć oba kraje. W dziedzinie polityki zagranicznej, finansów i polityki gospodarczej miały one stanowić jeden organizm. Wspólny miał być również parlament, rząd oraz naczelne dowództwo. Aby ułatwić współdziałanie tak powstałego tworu, obywatele tych państw mieli otrzymać podwójne obywatelstwo ${ }^{8}$. Francuzi widząc w tym przede wszystkim chęć stworzenia z ich państwa kolejnej kolonii, propozycję odrzucili. Wobec tego Brytyjczycy udostępnili de Gaulle'owi od 18 czerwca, rozgłośnię BBC w Londynie. W dniu tym generał ogłosił swe stanowisko, w którym podkreślał konieczność i wolę walki aż do ostatecznego zwycięstwa.

Z nadejściem 19 i 20 czerwca plan emigracji władz do Afryki stawał się coraz bardziej realny. Uzyskano poparcie prezydenta, a Petain wyraził zgodę. Natomiast Rezydent Generalny Francji w Maroku, i (od 1939 r.) Głównodowodzący Teatru Działań w Afryce Północnej - gen. Charles Nogues, informował o gotowości przyjęcia rządu i 20tys. żołnierzy oraz o gotowości do prowadzenia wojny po otrzymaniu pomocy z Wielkiej Brytanii i Stanów Zjednoczonych?.

Reasumując, Francja mogła w tym czasie liczyć na wciąż nietkniętą flotę (czwartą na świecie), sto dwadzieścia tys. żołnierzy ewakuowanych spod Dunkierki, następne sto tys. można było przewieść do Afryki. Realna była też ewakuacja niemal całego lotnictwa do Afryki, a istnienie legalnego

\footnotetext{
Tamże, s. 61-62.

7 Tamże, s. 64.

8 Tamże, s. 65-66.

9 Tamże, s. 70.
} 
rządu niewątpliwie zwiększyłoby opór i nie pozwoliło Hitlerowi na administrowanie okupowaną Francją.

III Rzesza skrupulatnie wykorzystywała możliwość ingerowania w wewnętrzne sprawy Francji Vichy. Co więcej, sami dygnitarze francuscy wychodzili naprzeciw z własnymi propozycjami, korzystnymi dla Niemiec, w celu zapewnienia jak najlepszej pozycji dla swego nowego państwa. W kręgu polityków Vichy mówiło się nawet o swoistym podziale ról. I tak Niemcy miały zająć się Europą, natomiast Francuzi mieli skoncentrować swe zainteresowania na polityce kolonialnej. Nie byli jednak w stanie dostrzec, że to III Rzesza rozdawała wszystkie karty i nie miała zamiaru dopuszczać do współudziału kadłubkowej Francji.

W myśl rodzącej się „Rewolucji Narodowej” zaczęto wprowadzać zmiany systemowe. Już w głosowaniu z 10 lipca przeforsowano projekt o zmianie konstytucji, który uchwalono stosunkiem głosów 569 do 80 . W myśl owego „Article unique" - Petain stawał się dyktatorem o nieograniczonej niemal władzy ${ }^{10}$.

Hasła rewolucji z 1789 r. - „Wolność, Równość, Braterstwo”, zastąpiono przez nowe - „Praca, Rodzina, Ojczyzna”. Zmiany, jakie kryły się pod tymi hasłami, swym charakterem zbliżyły Państwo Francuskie do państw faszystowskich. Do najważniejszych postanowień, obejmujących również swym zakresem kolonie i politykę wobec nich, należały ustawy, które łamały zasady równości wszystkich obywateli wobec prawa; dużego znaczenia nabrało obywatelstwo (oparte na prawie krwi), które wymagane było w razie starań o pozycję urzędnika państwowego. Zakwestionowano także program naturalizacji, cofano obywatelstwo bądź to ze względów politycznych, bądź na żądanie niemieckie; mieszkańcom terytoriów zamorskich stawiano przeszkody na drodze uzyskania obywatelstwa metropolii; cofnięto też tzw. Dekret Cremieux z października 1870 r., który nadawał Żydom algierskim obywatelstwo francuskie ${ }^{11}$. W sierpniu $1940 \mathrm{r}$. Hitler na spotkaniu z Lavalem, zaproponował niemiecko-francuską współpracę w Afryce. W 1941 r. wybuchło antybrytyjskie powstanie w Iraku. W maju Niemcy zwróciły się do Vichy o możliwość wykorzystania lotnisk syryjskich i broni z tamtejszych magazynów, na co otrzymały odpowiedź pozytywnąa ${ }^{12}$.

W dniach 21-28 maja 1941 r., odbyły się rozmowy francusko-niemieckie w Paryżu. Prowadził je już nowy przywódca Vichy - adm. Darlan. W nocy z 27 na 28 maja podpisano tzw. Protokoły paryskie, które dotyczyły

\footnotetext{
${ }^{10}$ Tamże, s. 78.

${ }^{11}$ T. Janasz, Państwo Francuskie 1940-1944. Ideologia, organizacja, prawo, Wrocław 1977, s. 143, 144, $148,152$.

${ }^{12}$ J. Eisler, dz.cyt., s. 160.
} 
współpracy tych państw w Syrii i Iraku, Afryce Północnej oraz Afryce Zachodniej i Równikowej ${ }^{13}$. Mimo tego, wobec klęsk Wermachtu w Afryce Północnej, w styczniu 1942 r. zaczęto sondować opinię co do wkroczenia Afrika Korps do Tunisu. Kwestia ta powróciła jeszcze po ustąpieniu adm. Darlana i objęciu głównej roli przez Lavala. 9 listopada wobec oporu strony francuskiej, Hitler zagroził przymusowym zajęciem Tunisu i dodatkowo strefy „wolnej”, tj. nieokupowanej Francji kontynentalnej. Dwa dni później, po wkroczeniu wojsk niemieckich, stało się to faktem. Jednak dopiero 26 listopada postanowiono unieszkodliwić flotę Vichy. Części okrętów udało się uciec, natomiast reszta poddała się rozkazowi naczelnego dowódcy marynarki i samounicestwiła się ${ }^{14}$. Żołnierze kolaboracyjnej Francji, na przełomie lat 1942 i 1943, w ramach Phalange Africaine, brali udział w walkach z Aliantami w Tunisie ${ }^{15}$.

Jednak nie wszyscy Francuzi zgodzili się na współpracę z Niemcami. Na czele walczącej Francji stanął gen. de Gaulle. Oficjalne uznanie go przez Aliantów miało miejsce 23 czerwca 1940 r., w dniu tym powstał też Komitet Narodowy Francji i stanął na czele Wolnych Francuzów (WF).

Obawiając się, iż flota Vichy może być wykorzystana po stronie państw Osi, Alianci przeprowadzili w lipcu 1940 r. atak na bazę morską w Mers-el Kebir. Nie poinformowanie WF o tej operacji, położyło podwaliny pod nieufność de Gaulle'a do Anglosasów ${ }^{16}$.

Na obszarze Czarnej Afryki panował silny duch walki z państwami Osi. Świadczyły o tym liczne manifestacje w miastach na tym obszarze, z poparciem dla $W^{17}$. W Kamerunie, dawnej kolonii niemieckiej, ludność francuska i tubylcza była oburzona aktem kapitulacji. Obawiała się powrotu Niemców. Czad, gdzie gubernatorem był czarnoskóry Felix Eboue, był zdecydowany na dalszy opór. Jednak dużo zależało od stanowiska Konga i jego gubernatora Boisson'a. Jako zwierzchnik Francuskiej Afryki Równikowej, miał wpływ na mniejsze regiony, jak np. Ubangi czy Gabon, które na razie wykazywały postawę zachowawczą w stosunku do zaistniałej sytuacji. Boisson do połowy lipca 1940 r. nie zajął wyraźnego stanowiska, a potem udał się do Dakaru, będącego ostoją Vichy.

Wobec tego zwolennicy de Gaulle'a dokonali 28 sierpnia 1940 r. zamachu wojskowego w Kongo, co niemal wiązało się z przejęciem władzy nad

\footnotetext{
${ }^{13}$ Tamże, s. 163.

${ }^{14}$ Tamże, s. 188.

${ }^{15}$ Tamże, s. 102.

${ }^{16}$ Ch. De Gaulle, Pamiętniki, Warszawa 1962, T. I, s. 76.

${ }^{17}$ Tamże, s. 89.
} 
całą Afryką Równikową ${ }^{18}$. Wahające się do tej pory Ubangi, w obecnej sytuacji przyłączyło się do WF. Nieliczne garnizony, które stawiały opór, po zawarciu ugody zostały internowane do Afryki Zachodniej. Niemal cała Afryka Równikowa stanęła po stronie de Gaulle'a. Wyjątek stanowił Gabon, którego gubernator musiał zmienić zdanie po przybyciu floty z Dakaru ${ }^{19}$.

W przeciwieństwie do obszaru równikowego, władza we Francuskiej Afryce Zachodniej była silnie scentralizowana i mocno powiązana z Afryką Północną. Potężnym ośrodkiem był Dakar, który jako fort miał nowoczesne baterie artyleryjskie. Ponadto stacjonowało tu liczne lotnictwo, a w porcie stał uszkodzony pancernik „Richelieu” ${ }^{20}$.

31 sierpnia 1940 r. wyruszyła ekspedycja w kierunku Dakaru. Wraz z Francuzami płynęli jeszcze Brytyjczycy i Holendrzy. Alianci sądzili, iż samo pojawienie się potężnej floty pozwoli przekonać kolonie do zmiany stron. Jednak w drodze, nastąpiło spotkane z flotą Vichy, płynącą do Konga. Tym samym Alianci nie mogli liczyć już na efekt zaskoczenia, gdyż okręty Państwa Francuskiego skierowały się do Dakaru. Obie floty spotkały się jeszcze 23 września w Dakarze. Cała operacja okazała się fiaskiem. Samoloty Aliantów zostały ostrzelane, nie udało się przeprowadzić desantu na plaże, doszło nawet do wymiany ognia między twierdzą a okrętami brytyjskimi. Chcąc uniknąć bratobójczych walk, Alianci wycofali się ${ }^{21}$.

Obrano nowy cel - pozostający pod władzą Vichy ostatni skrawek Afryki Równikowej, czyli Gabon. Operacja rozpoczęta 27 października zakończyła się sukcesem w połowie listopada. Gabon został zajęty, a nowym gubernatorem został Parant. Już 2 września 1940 r., do WF przyłączyły się posiadłości francuskie w Oceanii. Ponadto utworzył się tam Rząd Tymczasowy. Tydzień później gubernator Bonvin zgłosił akces posiadłości w Indiach. We wrześniu na stronę de Gaulle przeszły też Nowe Hebrydy, a ich gubernator - Sauto, zajął Numeę 22 .

Znajdujące się w pobliżu Kanady St. Pierre i Miquelon, 14 września 1940 roku poprosiły Wielką Brytanię o wsparcie. Dopiero jednak atak Japończyków na Pearl Harbour, skłonił Anglię do postanowienia, iż tereny te należy przywrócić WF. Z tych samych powodów postanowiono przywrócić WF Nową Kaledonię, Markizy, Wyspy Towarzyskie, Wyspy Taumotu i Tahiti. Co prawda Vichy pod koniec grudnia 1941 roku próbowało wzniecić w nich powstanie przeciw de Gaulle'owi, to już w styczniu 1942, na mocy umów ze Sta-

\footnotetext{
${ }^{18}$ Tamże, s. 94.

19 Tamże.

${ }^{20}$ Tamże, s. 95.

${ }^{21}$ Tamże, s. 99-105.

${ }^{22}$ Tamże, s. 102.
} 
nami Zjednoczonymi stały się one bazami dla sił amerykańskich. Umowy te były korzystne dla WF, gdyż po zakończeniu wojny miały być one zwrócone Francji, wraz z całą infrastrukturą rozbudowaną przez Stany Zjednoczone. Doniosłym efektem tego zbliżenia, było uznanie 1 marca 1942 przez USA dawnych wysp francuskich na Pacyfiku, za podległe Francuskiemu Komitetowi Narodowemu. To samo w stosunku do Afryki Równikowej, miało miejsce trzy dni później.

Madagaskar znajdował się pod zwierzchnictwem rządu Vichy. W obawie o możliwość zawarcia umów Oś-Vichy i wykorzystania go przez Japonię, a tym samym zagrożeniu interesom Wielkiej Brytanii na Oceanie Indyjskim, Churchil nie konsultując się z WF zdecydował o stworzeniu przyczółka na wyspie. Desant wysadzony 5 maja 1942 roku zajął Diego-Suarez, jednak na tym zaprzestano dalszych działańn ${ }^{23}$. Pomimo rozmów de Gaulle’a z Brytyjczykami na temat przynależności wyspy, faktyczna władza pozostawała w rękach vichystowskiego generała gubernatora Aneta. Dopiero po pięciomiesięcznych, bezowocnych rozmowach z gubernatorem wyspy, Brytyjczycy w październiku 1942 r. wznawiają działania wojenne bez udziału WF i wkrótce przejmują całą wyspę. Na skutek silnych zakusów brytyjskich, co do utrzymania władzy we własnych rękach, przekazanie koloni Francuzom miało miejsce dopiero 14 grudnia 1942 roku, na mocy decyzji dowództwa strategicznego Aliantów. Władza zwierzchnia objęła też sąsiednie terytoria i wyspy: Komorskie, Crozet, Karguelen, Saint-Paul. Z ramienia WF władzę przejął gen. Legentilhomme, jako wysoki komisarz, z siedzibą $\mathrm{w}$ stolicy Madagaskaru ${ }^{24}$.

11 listopada 1942 r. do WF przyłączono Reunion. Miało to strategiczne znaczenie, ze względu na możliwość wykorzystania wyspy przez państwa Osi, wobec utraty potencjalnej bazy, jaką mógł stać się Madagaskar ${ }^{25}$. Dla polityki aliantów ogromne znaczenie miało Francuskie Somalii (Dżibuti), które - w razie zajęcia przez Oś - mogło zagrozić tranzytowi przez Kanał Sueski i Morze Czerwone. Za porozumieniem z Wielką Brytanią, siły WF przejęły Dżibuti z rąk Vichy 26 listopada 1942 r. Cztery dni później miało miejsce usytuowanie się władz we Francuskim Somalii. Od tego czasu tereny wokół Oceanu Indyjskiego znajdowały się po stronie de Gaulle ${ }^{26}$.

Już od 1941 r., kolonie francuskie w Ameryce Pd. - Gujana oraz w jej pobliżu - Martynika i Gwadelupa, były obiektem penetracji agentów WF,

\footnotetext{
${ }^{23}$ R. Cornevin, M. Cornevin, Histoire de l'Afrique. Des origines a la deuxieme querre mondiale, Paryż 1964, s. 389

${ }^{24}$ Ch. de Gaulle, dz.cyt., T. II, s. 56-57.

${ }^{25}$ Tamże, s. 74.

${ }^{26}$ Tamże, s. 77-78.
} 
m.in. Jeana Massipa. Jednakże dopiero z początkiem 1943 r., realnym stało się przyłączenie tych terenów do Francji Walczącej (FW) ${ }^{27}$. W marcu Gujana wystąiła z Państwa Francuskiego. 16 t.m. odbyła się manifestacja w stolicy, na cześć De Gaulle'a. Ponadto wysłano do niego telegram z wolą przyłączenia $\mathrm{się}^{28}$. Gubernator Martyniki - adm. Robert, w 1943 r. otrzymywał liczne petycje o woli przyłączenia się do de Gaulle’a. Sami przywódcy Francji Walczącej - de Gaulle i Giraud, wystosowali pismo do Roberta w kwietniu 1943 r. Mimo to postawa gubernatora była nieugięta, co więcej kontynuował on walkę z Ruchem Oporu. 18 czerwca 1943 r., Komitet Wyzwolenia z Vicarem Severe opowiedział się za de Gaulle'em. Sześć dni później odbyła się wielka manifestacja ludności Martyniki. Ostatecznie 30 t.m., adm. Robert ugiął się i poprosił USA o pośrednictwo w mediacjach. Jego decyzja przekonała Gwadelupę do odstąpienia od dawnego kursu i przyłączenia się do FW. 14 lipca 1943 r. przybył delegat Komitetu Wyzwolenia Narodowego ${ }^{29}$.

Maghreb był kluczowym punktem kolonialnego imperium francuskiego. Ważność tego obszaru wynikała z wielu czynników: dostarczał on ludzi do armii, surowców do przemysłu i innych wartościowych minerałów. Ponadto na stałe mieszkał tu około milion obywateli francuskich, a na jego obszarze znajdowało się dogodne miejsce do wielkich inwestycji. W końcu miał też znaczenie strategiczne, tj. był drogą łącząca metropolię z koloniami: Francuską Afryką Zachodnią i Francuską Afryką Równikową. Jednakże klęska Francji w 1940 roku osłabiła wpływy francuskie, a obok drugiego ważnego na tym terenie imperium - Wielkiej Brytanii, od drugiej połowy lat 30. zaczęły wkraczać tutaj wpływy włoskie.

Od początku powstania kolaboracyjnego rządu Vichy, Tunezja uznawała jego zwierzchnictwo, to jednak nie przeszkodziło to wojskom niemiecko-włoskim rozpoczęcia jej okupacji od listopada 1940 roku. Podejmowane przez beja Muhammada al-Munsifa próby zmiany statusu protektoratu okazały się bezowocne ${ }^{30}$.

Z końcem 1942 roku brytyjska 1. Armia wraz z żołnierzami FW nieskutecznie walczyła o opanowanie Tunezji. Dopiero klęska pod Kesserine i połączenie armii brytyjskich z korpusem amerykańskim, po przełamaniu obrony pod Mareth, przesądziło o losie państw Osi na tym obszarze. 7 maja 1943

\footnotetext{
${ }^{27}$ Od wiosny 1942 roku „Wolni Francuzi” zostali przemianowani na „Francję Walczącą”; Tamże, T. I, s. 212.

${ }^{28} \mathrm{~W}$ sytuacji tej objawił się charakter polityki Stanów Zjednoczonych, które zamiast de Gaulle, wolały generała Giraud. W tym celu opóźnili wysłanie telegramu, by Giraud mógł przybyć przed de Gaulle'a; Ch. de Gaulle, Pamiętniki, T. II, s. 155.

${ }^{29}$ Tamże, s. 155-156.

${ }^{30}$ Historia krajów arabskich 1917-1966, D. R. Woblikow (red.), Warszawa 1974, s. 515.
} 
roku zajęto Tunis. 9 maja skapitulowały wojska niemieckie w Afryce, a cztery dni później to samo uczyniły wojska włoskie ${ }^{31}$. Nastąpiło też przywrócenie władzy Francji nad Tunezją, a w celu ukrócenia dalszych prób walki o autonomię, pozbawiono władzy beja i powołanego przez niego rząd. Podobnie jak Tunezja, Maroko znalazło się pod władzą Vichy. Było wykorzystywane przez państwa Osi jako baza żywnościowa i strategiczna. Jednak w kwestii gospodarczej, po osłabieniu pozycji Francji, jej miejsce zaczęły zajmować Stany Zjednoczone. Na mocy umowy Weygand-Murphy z końca 1940 roku, USA mogło dostarczać do Afryki Północnej niektórych towarów przemysłowych, pod warunkiem, iż nie trafią one w ostatecznym obiegu do państw Osi. Zerwano ją jednak już z końcem $1941 \mathrm{roku}^{32}$.

W listopadzie 1942 zaczęła się inwazja wojsk anglo-amerykańskich, w wyniku której Francja faktycznie straciła kontakt ze swą kolonią. Pomimo stawianego oporu podczas walk i sprzeciwu de Gaulle'a, administracja Vichy została pozostawiona przez Aliantów. USA miało własne plany wobec Maroka. Objawiło się to na konferencji dwustronnej, prezydenta Stanów Zjednoczonych z sułtanem, w Casablance 22 stycznia 1943 roku. W zamian za pomoc dla kolonii, oba państwa miały przeciwdziałać polityce kolonialnej Francji i Wielkiej Brytanii na rzecz „wolnej konkurencji”, co niewątpliwie otwierało drogę dla gospodarczej ekspansji USA ${ }^{33}$. W tym czasie powstaje też Komunistyczna Partia Maroka, której program zakładał prawo do samostanowienia, a tym samym lansował hasła niepodległościowe. Był on też za walką z hitleryzmem. Z kolei w 1944 roku powstała Partia Niepodległości. Jej manifest z 11 stycznia 1944 roku rozbudził dążenia niepodległościowe. Skierowany do dowództwa alianckiego, administracji francuskiej i sułtana, mówił o potrzebie zjednoczenia Maroka (wraz z hiszpańską strefą) oraz o pełnej samodzielności w stanowieniu o sobie. Władze francuskie zaczęły zwalczać te dążenia, a rozpoczęte aresztowania wywołały zamieszki, które zostały krwawo stłumione ${ }^{34}$.

Algieria podobnie jak Tunezja i Maroko znalazła się pod władzą Vichy. Ultimatum państw Osi z 29 lipca 1942 roku mówiło o przejęciu baz morskich w Algierze, Casablance i Dakarze od Państwa Francuskiego ${ }^{35} .8$ listopada 1942 lądowały wojska Aliantów w Afryce. Już dwa dni później adm. Jean Francis Darlan, dotychczasowy zarządca tych terenów, zaproponował współpracę Aliantom za utrzymanie swego stanowiska. Zdrada ta była bezpośrednim po-

\footnotetext{
${ }^{31}$ Zarys dziejów Afryki i Azji, A. Bartnicki (red.), Warszawa 1996, s. 203.

${ }^{32}$ Historia krajów arabskich, dz.cyt., s. 589.

${ }^{33}$ Tamże, s. 589.

${ }^{34}$ Tamże, s. 590.

${ }^{35}$ Tamże, s. 550.
} 
wodem zajęcia Państwa Vichy na kontynencie przez Oś. Po opanowaniu Algierii, podobnie jak $\mathrm{w}$ przypadku Maroka pozostawiono $\mathrm{u}$ władzy administrację Vichy z adm. Darlanem, którego od maja 1943 zastąpił Giraud.

W czerwcu 1943 roku utworzono Francuski Komitet Wyzwolenia Narodowego (FKWN), na którego czele stanął de Gaulle. Tymczasowo mieścił się on w Algierii. W lipcu 1944 roku FKWN przemianowano na Tymczasowy Rząd Francuski i po wyzwoleniu Francji przeniesiono go do Paryża ${ }^{36}$.

Lata 1943-1945, przebiegły pod znakiem nieurodzaju. Spowodował on migrację ludzi ze wsi do miast. Wobec faktycznego zerwania $\mathrm{z}$ dostawami z zewnątrz (z metropolii), zaczęła rozwijać się własna produkcja, co podniosło prestiż społeczny burżuazji. Jej przedstawiciele kilkakrotnie kierowali apele do władz francuskich pod koniec roku $1942 \mathrm{i}$ w pierwszej połowie 1943 o uznanie praw do samostanowienia, swobód politycznych i przeprowadzenia wyborów do Zgromadzenia Konstytucyjnego. Reakcja władz francuskich polegała na nawiązaniu kontaktu z reakcyjną częścią burżuazji, która za zapewnienie korzyści klasowych zgodziła się na dekret de Gaulle'a z 7 marca 1944 roku, czyli na powrót przedwojennej polityki asymilacji. Zwolennicy niepodległości utworzyli Unię Przyjaciół Manifestu i Wolności, która pomimo sprzeciwu swoich przywódców rozpoczęła 8 maja 1945 roku powstanie na wschodzie Algierii ${ }^{37}$. Francuzi wysłali poważne siły kolonialne, sięgnięto nawet po uzbrojenie jeńców włoskich, które to stłumiły powstanie zabijając około 40 tys. Algierczyków. Represje i aresztowania trwały nadal, a 15 maja 1945 roku rozwiązano Unię Przyjaciół Manifestu i Wolności ${ }^{38}$.

Po kapitulacji Republiki Francuskiej, teren Syrii i Libanu został poddany niemiecko-włoskiej komisji do spraw zawieszenia broni ${ }^{39}$. Miało to na celu wprowadzenie w przyszłości porządku faszystowskiego. Mimo to Francja ogłosiła „kontynuowane misji w krajach Lewantu”" . W lutym 1941 w Syrii, poczynając od Damaszku wybuchł strajk powszechny przeciw polityce grabieży kraju. W jego wyniku władze mandatowe zmuszone były pójść na ustępstwa, a syryjski ruch oporu pomógł WF w okresie czerwiec-lipiec 1941 $\mathrm{w}$ wypędzeniu agentury faszystowskiej z Syrii i Libanu ${ }^{41}$. Bezpośrednim powodem tej współpracy była wypowiedź gen. Catroux z 8 czerwca 1941,

\footnotetext{
${ }^{36}$ Tamże, s. 551.

${ }^{37}$ Tamże, s. 552.

${ }^{38}$ Tamże, s. 553.

${ }^{39}$ Tamże, s. 67. Na temat polityki niemiecko-włoskiej względem Syrii i Libanu, patrz: Zarys dziejów Afryki i Azji, dz.cyt., s. 208-209.

${ }^{40}$ Tamże, s. 102.

${ }^{41}$ Tamże, s. 68.
} 
który obiecał przyznanie Syrii i Libanowi niepodległości po wyzwoleniu. W miesiącu tym WF i wojska brytyjskie wkroczyły do Lewantu ${ }^{42}$. Wielka Brytania miała zostać gwarantem decyzji o przyznaniu niepodległości. Jednak już w sierpniu tego roku na skutek sporu de Gaulle z brytyjskim ministrem rezydentem na Bliskim Wschodzie, zmodyfikowano tą decyzję. Anglia uznała „specyficzne stanowisko” Francji w Syrii, i oprócz zachowania statusu mandatowego, przywrócono kontrolę Francji nad kluczowymi instytucjami $^{43}$. Jednak rozbudzone nadzieje narodu syryjskiego i groźba powstania, już 27 września 1941 r. spowodowały zmianę stanowiska Francji i ostatecznie przyznano Syrii niepodległość, a 22 listopada 1941 r. Libanowi. Ciche konflikty między WF i Wielką Brytanią trwały, i choć Brytyjczycy nie kwestionowali praw Francuzów do tych terenów, to faktycznie były one ignorowane przez nich ${ }^{44}$. W 1943 r. przywrócono konstytucję w Syrii i Libanie oraz zezwolono na zorganizowanie wyborów do parlamentu. W grudniu $1943 \mathrm{r}$. usunięto zapis o mandacie Francji w sprawie Syrii. Nastąpiło też oddawanie Syryjczykom urzędów i ministerstw oraz obiecano wycofać armię̨ ${ }^{45}$. Opieszałość Francji w zakresie ostatniego punktu wywołała w maju 1945 r. wojnę kolonialną, do której wkrótce wmieszała się Wielka Brytania. Nie poprawiło to sytuacji Syrii, wprowadziło natomiast urzędników angielskich, obok francuskich, do instytucji państwowych. W Libanie po decyzji prezydenta Biszary al-Churiego o usunięciu wpływów metropolii, delegat Francji nakazał jego aresztowanie wraz z premierem i kilkoma członkami rządu ${ }^{46}$. Reakcja narodowa była tak silna, iż doszło nawet do współpracy chrześcijan z muzułmanami w ramach utworzonego Kongresu Narodowego. Ostatecznie 22 listopada 1943 r. Francja wycofała się ze swych planów i nastąpił powrót do poprzedniego stanu. Proklamowano niepodległość, z więzienia uwolniono prezydenta i innych urzędników państwowych, a rząd powrócił do obrad. Oprócz kolejnej próby z maja 1945 r., Francja po raz ostatni chciała wymusić zgodę Libanu na swą specjalną pozycję pod koniec 1945 roku. Pomimo tajnych umów i współpracy francusko-brytyjskiej, ona również zakończyła się fiaskiem ${ }^{47}$. Ostatecznie zawarto traktat, w myśl którego Wielka Brytania i Francja miały wycofać się z Libanu do końca 1945 roku $^{48}$. Między Francją i Wielką Brytanią przez cały czas trwała tajna współpraca w kwestii Syrii i Li-

\footnotetext{
${ }^{42}$ A. Hourani, Historia Arabów, Gdańsk 1995, s. 353.

${ }^{43}$ Historia krajów arabskich, dz.cyt., s. 68.

${ }^{44}$ Tamże, s. 198

${ }^{45}$ Tamże, s. 69.

${ }^{46}$ Tamże, s. 103-104.

${ }^{47}$ Tamże, s. 106.

${ }^{48}$ A. Hourani, dz.cyt., s. 354.
} 
banu ${ }^{49}$. Dopiero ONZ doprowadziło do wycofania się tych państw, nastąpiło to jednak w kwietniu $1946 \mathrm{r}$.

Innym dużym obszarem kolonialnym były Indochiny. Składały się z Kambodży, Laosu i trzech krajów zamieszkałych w większości przez Wietnamczyków - Annam ze stolicą w Hue, podległy mu Tonkin z Hanoi i Kochinchina ${ }^{50} \mathrm{z}$ Sajgonem. W Hanoi rezydował francuski gubernator generalny Indochin ${ }^{51}$. Azja Południowo-Wschodnia miała być integralną częścią przyszłego imperium azjatyckiego pod zwierzchnictwem Japonii. Obszar Indochin słynął z wydajnych pól ryżowych oraz obfitował w kauczuk, cynę, węgiel i ropę naftową, która była szczególnie potrzebna Japonii wobec braku surowców na wyspach. Po klęsce Francji, kolonie azjatyckie zostały odcięte od metropolii. Pozycja Wielkiej Brytanii też nie była silna w tym rejonie. Stąd Tokio dość szybko zaczęło wymuszać na rządzie Indochin różne koncesje. Do pierwszych doszło już w 30 sierpnia 1940 r., kiedy to pod pozorem zapewnienia bezpieczeństwa zawarto pierwsze umowy. Nippon potwierdził w nich suwerenność, w zamian za uznanie swej uprzywilejowanej pozycji na tym terenie. We wrześniu (22) rozszerzył swoje uprawnienia o prawo do korzystania $\mathrm{z}$ tonkijskich lotnisk, portu w Haipongu, wyładunku żołnierzy zmierzających do Guanxi i pozostawienia sił umożliwiających kontrolę nad wykonywaniem wyżej wymienionych umów. W 1940 roku wymuszono jeszcze prawo ustanowienia japońskich kontrolerów na kolei i stacjonowania kontyngentu wojskowego w Tonkinie ${ }^{52}$. Już w czerwcu $1940 \mathrm{r}$. podpisano układ japońskosyjamski, o wzajemnej obronie. Syjam od 1939 r. zwany Królestwem Tajów, także zaczął realizować swoją wielką politykę. Jednak na swej drodze ku zjednoczeniu musiał wystąpić przeciwko Francji, gdyż mieszkający w Indochinach Laotańczycy i Khmerowie byli powszechnie uważani za Tajów. Doszło do starć oddziałów francuskich i syjamskich, choć nie wypowiedziano wojny. Strona tajska odniosła sukces na lądzie, natomiast flota francuska panowała na morzu. Pomimo umów o „bezpieczeństwie”, Japonia zachowała neutralną postawę. Co więcej wymusiła na rządzie Vichy, w umowie z 9 maja 1941 r., odstąpienie Syjamowi zachodniej Kambodży tj. terenu o powierzchni 69 tys. km kw. i z 335 tys. mieszkańców ${ }^{53} .20$ lipca 1941 roku Japonia wystosowała do Indochin ultimatum, grożąc wkroczeniem żołnierzy.

\footnotetext{
${ }^{49}$ Tamże, s. 71.

${ }^{50}$ Kochinchina była kolonią, z której osiedli Francuzi mogli wybierać deputowanego do parlamentu w Paryżu; Krasuski, dz.cyt., s. 14.

${ }^{51}$ Tamże.

${ }^{52}$ W. Olszewski, Historia Wietnamu, Wrocław-Warszawa-Kraków 1991, s. 318.

${ }^{53}$ Znamienny jest fakt, że miejscem podpisania umowy był japoński krążownik zacumowany w porcie w Sajgonie.; B. Maszlanka, Cztery oblicza militaryzmu, Warszawa 1971, s. 281.
} 
Bez względu na decyzje, wojska były przygotowane przekroczyć granicę wraz z nastaniem 22 lipca. Wobec przewagi japońskiej, adm. Darlan ustąpił i przystał na warunki japońskie ${ }^{54}$. Pogorszeniu uległa też sytuacja wewnętrzna kolonii. W czasie walk z Syjamem, nacjonalistyczne ugrupowania wietnamskie wywołały powstanie antyfrancuskie. Pomimo umów ze stroną francuską, Japończycy nie tylko nie udzielili wsparcia, ale co więcej, wywiad japoński był prawdopodobnie uwikłany w dostarczanie broni dla powstańców. Miało to na celu pozyskanie patriotów wietnamskich dla sprawy japońskiej ${ }^{55}$.

Ludność cierpiała podwójnie. Pozostawiona administracja francuska sprawowała normalną władzę kolonialną, natomiast Japończycy, na mocy umów z lat 1940-1941, bezpardonowo eksploatowali $\mathrm{kraj}^{56}$. Od 1942 r. narastały nastroje niepodległościowe, wzmagane przez powstały we wrześniu 1941 r. Viet Minh. Z końcem 1941 r. na terenie francuskich Indochin powstały pierwsze obozy partyzantów. Początki tego ruchu rodziły się pod auspicjami Chin, które w ten sposób chciały rozbudzić walkę z Japonią i mieć wpływ na swego sąsiada w przyszłości. Dlatego też we wrześniu 1943 r. uwolniono Ho Chi Minha. Nie pozostało to bez reakcji Francji Walczącej. De Gaulle już w grudniu tego roku zapowiedział oficjalnie powrót Francji do Indochin $^{57}$. W marcu 1945 r. Japończycy zdecydowali się na oficjalną okupację Indochin, stawiając na czele państwa marionetkę - cesarza Bao Daia. Ten 11 marca przystał na taki stan rzeczy, a 17 marca uformował się projapoński rząd. De Gaulle gotów był współdziałać z Viet Minhem, a jako gest pojednawczy przyznał Wietnamowi autonomię $e^{58}$. W kwietniu doszło do podziału i tworzenia zalążków władzy. I tak baodaiwiści uformowali się w Hue, a rewolucjoniści w Vic Bac. 17 sierpnia miał miejsce przewrót w Hanoi, za którym stał Viet Minh. Zmusił on do abdykacji cesarza 30 sierpnia. W tym samym dniu wydano też dekret rozwiązujący francuskie zwierzchnictwo, a 2 września Ho Chi Minh uroczyście proklamował powstanie Demokratycznej Republiki Wietnamu ${ }^{59}$.

Druga Wojna Światowa była początkiem schyłku „starego” francuskiego imperium kolonialnego. W jej wyniku część kolonii zerwała całkowi-

\footnotetext{
${ }^{54}$ Ponadto $\mathrm{w}$ archiwum japońskiego Ministerstwa Spraw Zagranicznych odnaleziono dokument datowany na 28 września 1940 r., który mówił o podziale Indochin na trzy części. Kambodża miała przypaść Syjamowi, pn. część wraz z Tonkinem do Chin (za ewentualny pokój), a reszta jako niepodległe (faktycznie kolonia japońska) państwo.; B. Maszlanka, dz.cyt., s. 284285.

${ }^{55}$ Zarys dziejów Afryki i Azji, dz.cyt., s. 218.

${ }^{56}$ Tamże, s. 225.

${ }^{57}$ W. Olszewski, Historia Wietnamu, Wrocław-Warszawa-Kraków 1991, s. 324-325.

${ }^{58}$ Tamże, s. 328.

${ }^{59}$ Tamże, s. 332.
} 
cie stosunki z metropolią i uzyskała pełną samodzielność. Chociaż w Indochinach toczyła się jeszcze bardzo długo wojna kolonialna, to Francja nie miała już szans na zwycięstwo. Wynikało to zarówno z jej charakteru - wojny partyzanckiej, z niemal całym narodem, jak i zmian, jakie dokonały się na świecie. Francja przestała być imperium, które mogło wywierać wpływ na politykę światową. Co więcej, stała się tylko „klientem” w nowej rywalizacji, jaką nawiązała się między Stanami Zjednoczonymi i Związkiem Radzieckim.

Z tych samych powodów nie dało się utrzymać starego porządku, w koloniach, które jeszcze udało się zatrzymać. Pomimo wielu lat polityki asymilacji, powoli rodziła się $\mathrm{w}$ nich nowa świadomość narodowa. Także świat oczekiwał „ucywilizowania” stosunków na linii metropolia-kolonia. W przypadku państw arabskich, kolonie odnalazły sojusznika w innych krajach, już niepodległych, które stały się ich rzecznikami na arenie międzynarodowej.

Projekty reform pojawiły się już w czasie wojny. Cel taki przyświecał chociażby konferencji w Brazzaville w 1944 roku. Jednak odbywała się ona jeszcze w dawnym duchu i nie przedstawiała atrakcyjnej oferty do pozostania w związku z Francją. Dopiero wojna w Indochinach i wstrząsy w Algierii, uzmysłowiły Francuzom zmianę oblicza ówczesnego świata, w którym nie było już miejsca dla francuskiego imperium kolonialnego. 


\section{French colonies between 1940 and 1945}

After Great Britain, France was the second largest empire, possessing colonies in Asia, Africa, North and South America. 69 million of citizens (among whom 41 million lived in continental France) and nearly 12 million square kilometers were under French control.

As a result of the defeat in 1940s campaign, French territory was occupied by German forces. South part of the country was transformed into État Français, governed by Pétain, permanently influenced by racial policy of Third Reich.

There existed an opposition towards Vichy government, leaded by de Gaulle and supported by Allies. Although these forces had managed to recapture French Equatorial Africa in 1940, a similar attempt concerning French West Africa was unsuccessful until the arrival of American forces. Another problem for the French forces were the Arabic countries' independence movements leading to an antiFrench upraising in Algeria in 1945.

Until the end of 1942, all of French colonies around the Indian Ocean were attached to de Gaulle's France. South American properties were taken under French control a year later.

Although English and French troops entered Syria and Lebanon in 1941, strong national movements resulted in these two countries' independence. In spite of that, France, as well as Great Britain, both competing for the influence in the Middle East, was reluctant to leave this territory.

Since 1940, as a result of several agreements, Japan had been sending its army to French Indochina. In spite of previous Japan-Vichy agreement, in course of the undeclared war between Siam and France, Japan supported Siam, and France had to leave the western part of Cambodia. During that time, Vietnamese national movement was developing into the final form of Viet Minh, leaded by Ho Chi Minh. Since March 1945, Japanese occupation of Indochina had been taking place and resulted in a creation of puppet government with Bao Dai. On $2^{\text {nd }}$ September, as a result of Viet Minh's successful coup d'état, Democratic Republic of Vietnam was proclaimed, which constituted a direct reason of a long war with France.

Second World War brought a slow end to French colonial empire. North African independence movements were becoming stronger and stronger and, at the same time, Indochina national uprising broke out. As a result of the 1940s defeat and the collaboration with Axis, France could no longer be a leading empire and it was forced to pass its place to new world powers - the Unites States and the Soviet Union. 